\title{
Introducing Gunawangsa Manyar Hotel Through a Marketing Booklet
}

\author{
Larisa, E. \\ English Department, Faculty of Letters, Petra Christian University \\ Siwalankerto 121-131, Surabaya 60236, East Java, INDONESIA \\ E-mails : evilarisa@yahoo,com
}

\begin{abstract}
Gunawangsa Manyar Hotel is a three star hotel in the East of Surabaya. As a three star hotel, Gunawangsa Manyar Hotel also has competitors such as Swiss BelInn Manyar Hotel, Fave Hotel, Core Hotel, and Everbright Hotel. Compared to the competitors, Gunawangsa Hotel is not well known by many people. In introducing the hotel, they only use brochure and flyer for printed advertising. It means the tools they have are ineffective. Therefore, to introduce the hotel effectively, marketing booklet is the good solution for Gunawangsa Hotel since marketing booklet brings complete information needed by potential customers. The content of the booklet consists of company overview, product description, and contact information. In the product description, the USPs would be more emphasized. The USPs are obtained by the interview result with six guests of Gunawangsa Manyar Hotel.

Key words: marketing booklet, promotional tool, hotel
\end{abstract}

\section{INTRODUCTION}

The company that I did my internship is TS Suites but I did my project in Gunawangsa Manyar Hotel. The reason I did not do my project in TS Suites because the corporate gathering event that I offered was not approved by the representative. It would need much time to get the approval from Jakarta and could not guarantee it would be approved. Therefore, I tried to find another company which was Gunawangsa Manyar Hotel. I chose Gunawangsa Manyar Hotel because my friend worked in the Sales \& Marketing Department and she suggested me to do my project there. In few weeks later, I met the HR and Sales \& Marketing manager to get the information of Gunawangsa Manyar Hotel. The information was about the background, competitors, and problems they are facing.

First is about Gunawangsa Manyar Hotel. Gunawangsa Manyar Hotel is a three-star hotel and was established in 2012. It has two locations: one in Manyar and the other one in Merr. Gunawangsa Hotel Manyar is located in Menur Pumpungan no. 62 Surabaya. It has 124 rooms, adults and children's swimming pools, three meeting rooms, a coffee shop, and a lounge bar. Other facilities like spa, wifi and welcome drink are also available. Compared to its competitors, Gunawangsa Manyar Hotel is the cheapest three-star hotel in Surabaya. They also have the most complete facilities among other three-star hotels. They have a restaurant that provides Asian, Western, and Indonesian foods, and two types of swimming pool which are not owned by other three-star hotels. It is also located in a strategic area which is in the East of Surabaya and close to one of Surabaya's biggest shopping malls, Galaxy Mall, City Centre, and Airport.

As a three-star hotel, Gunawangsa Manyar Hotel has competitors such as Swiss BelInn Manyar Hotel, Fave Hotel, Core Hotel, and Everbright Hotel. These hotels are located in the same area which is in the East of Surabaya. Besides location, price, and facilities, all of them have their own uniqueness. First is Swiss BelInn Manyar Hotel. It is better than Gunawangsa Hotel because of the brand. They have an international brand so it is more famous and many people know them. Second is Fave Hotel. It has more branches than Gunawangsa Hotel. Fave Hotel has 3 branches and all of them are located in a strategic location. The locations are spread out in each area which is in the west, centre, and east of Surabaya. Next is Core Hotel and Everbright Hotel. These two hotels are new comers so they have newest and more modern building and room design.

Compared to its competitors, I think Gunawangsa Hotel is not well known by people. There are only few people who know Gunawangsa Manyar Hotel. It is also proven by the low occupancy. 
Same companies stay in Gunawangsa Manyar Hotel every month. It does not indicate any addition of a new company. The cause of this problem is the promotional tools that they used are not effective enough to introduce the hotel. They only use brochure, flyer, and poster. Brochure and flyer were put on the Front Office table and in the restaurant while the poster is put on the lift. They also have a television to display new package or promotion. In addition, they also used media such as radio, newspaper, and media social to increase brand awareness. Those promotional tools they used proved that brochure and flyer are not enough to introduce the hotel. In fact, brochure and flyer only bring little information and cannot show the uniqueness and product accurately while some of the potential customers want to know more about Gunawangsa Manyar Hotel since the brochure and flyer are given to the customers when sales team do sales visit. In the brochure and flyer, they only showed and offered special package for meeting room and foods. They also showed the product of Gunawangsa Hotel but in a small picture and not clear. By using only brochure and flyer, they cannot introduce and highlight its products. They can only introduce certain products like restaurant or spa. As I said before, there have been some potential customers who asked a booklet but they do not have the tool.

The problem of Gunawangsa Hotel is they have ineffective promotional tools to introduce the hotel and the best solution is a marketing booklet. This marketing booklet gave three benefits for Gunawangsa Manyar Hotel. First of all, it would help Gunawangsa Manyar Hotel to introduce itself to the potential customers. People could get the information about Gunawangsa Hotel and the uniqueness in the booklet. It means it would help the customers to have a clearer picture of Gunawangsa Hotel. This booklet would introduce and emphasize the facilities which are the restaurant and the swimming pools. Secondly, this marketing booklet could help Gunawangsa Hotel Manyar to increase its occupancy and income. Since the marketing booklet given to the prospects, the customers would know what exactly Gunawangsa Manyar Hotel is and what they sell. After that, many customers will be interested in staying in Gunawangsa Manyar Hotel. Lastly, Gunawangsa Manyar Hotel would have a new promotional tool. Besides brochure and flyer, there would be a marketing booklet to complete its promotional tools and could support the sales people in promoting the hotel. The benefits were not only felt by the company alone, but I would also get some benefits of doing this project. Firstly, this project helped to improve my communication skills. This project needed a lot of communication. I needed to make a deal with the HR and Sales \& Marketing Manager because I did not know them before. I also had to make a concept of the marketing booklet and consulted the concept of the booklet with the Marketing Manager. Secondly, doing this project gave me the experience and knowledge of making a promotional tool. Not only would I learn about the communication skills, but I would also learn other technical things to finally make a marketing booklet. I could learn more about how to make a good marketing booklet; I had to create a good concept to make the booklet interesting. Therefore, this project was the initial step for me to make more promotional tool in the future if people were impressed with my works. Lastly, this project could give an additional value to my CV and portfolio for my future career. When I apply for a job later on, I can show the employer that I have done some businesses by cooperating with a big company and made promotional tools for them. I would also show the committee experience during my study in the university. Therefore, I could show them that I can and have the skills to make a promotional tool for the company.

\section{METHODS}

There are several steps that I did to get the approval from the board of examiner and Gunawangsa Hotel for my Business Communication Final Project (BCFP) proposal. First of all, I wrote the proposal for my BCFP. In the proposal, I explained the most important problem that the hotel has, the reason why I chose a marketing booklet as my project, the purpose of making a marketing booklet, and what benefits Gunawangsa Hotel Manyar would get by having a marketing booklet. After getting the approval to make a marketing booklet, I met and talked with Mr. Toni, the Assistant HR Manager of Gunawangsa Manyar Hotel. In next two weeks, I also met and talked 
with the Sales and Marketing people to give the proposal. In the proposal, I put my interview result with six guests of Gunawangsa Hotel. The questions that I used in interview are :

- How good is Gunawangsa Hotel Manyar now - very good, good, ok, or poor?

- What makes them choose Gunawangsa Hotel Manyar?

- Who are the main competitors? Why?

- How do the business and its products differ from its competitors and their products?

- In what ways are the products better than their competitors'? The Quality, the Service, the Personnel, the Price, the Image, the Location, the Atmosphere, the Promotion, etc.?

- In what ways are the products worse than their competitors'? The Quality, the Service, the Personnel, the Price, the Image, the Location, the Atmosphere, the Promotion, etc.?

- What's the main cause of the problem with the business - poor quality, poor service, poor personnel, poor pricing, poor promotion, poor location/ place, etc. or simply lack of promotion?

- What's the best solution? Why?

This interview helped me to know the uniqueness of the hotel and how to emphasise its uniqueness. This also helped me to make Gunawangsa Hotel realized that its uniqueness must be more emphasized. After few days later, I was called to come to Gunawangsa Hotel to talk about the booklet content and the price. I only put one option and they finally agreed to pay me with this price.

\begin{tabular}{|l|c|c|}
\hline Purpose & Quantity & Cost \\
\hline $\begin{array}{l}\text { Editor } \\
\text { Designed by Dea Minerva } \\
\text { (Interior Design Student 2014 } \\
\text { at Petra Christian University) }\end{array}$ & 1 & \\
& & \\
\hline Printing \& Paper & & \\
\hline Total & 1 & Rp. $600.0000,--$ \\
\hline
\end{tabular}

\section{ANALYSIS AND FINDINGS}

This part contains the description of the tool, its users, and its purpose for the company. The product is "Introducing Gunawangsa Hotel through a Marketing Booklet". There are two sources that I used in choosing the elements of the marketing booklet. First, according to Kdavidson in ehow.com, a marketing booklet consists of four things; case studies, products/services, FAQ (Frequently Asked Questions), and contact information of the company. Second, according to Tara Hornor in business2community.com, a booklet contains five basic elements. The elements are the table of contents, the company overview, the products, the how-to guides or benefits, and the contact information. However, I chose only four components that will be put in the marketing booklet. First is table of contents. This part contains list of headings and corresponding page number. The heading lists are "About Gunawangsa Hotel" (page 1), "Rooms" (page 2), "Orchid Restaurant" (page 4), "Swimming Pool" (page 6), and "Other Facilities" (page 8). Second is company overview. This part contains general information about Gunawangsa Manyar Hotel. Third is product description. This part contains the four types of rooms. This part also contains one of the Unique Selling Points (USP) that Gunawangsa Hotel has, which is the facilities. For the facilities, I highlighted the restaurant and swimming pools and made it as main facilities. On the other side, I put another USP, which is the price in the company overview because I want the customers to have a first impression that Gunawangsa Hotel is the cheapest three-star hotel. Also, the reason I did not 
put the price in the booklet because prices are always changing every time. Therefore, I decided not to put the actual number in the booklet and only describe that Gunawangsa Hotel has affordable price with complete facilities. The other facilities such as fitness centre, a lounge bar, a coffee shop were also put in the booklet after restaurant and swimming pools. Lastly, contact information. This part contained address, telephone number, email, and social media account.

The target markets of this marketing booklet are companies or organizations and travel agencies. Since the price is cheaper than other three star hotels, it can be a selling point to attract companies who often have business trips. By seeing the marketing booklet, companies could understand what facilities that Gunawangsa Manyar Hotel provides with cheap prices. In addition, by giving a marketing booklet to the travel agencies, it will help Gunawangsa Manyar Hotel to introduce and promote the products to the customers.

The marketing booklet will be very useful for the hotel. The first advantage of the marketing booklet is the effectiveness. By using marketing booklet, there will be more space to introduce and emphasize the product and uniqueness of the hotel. On the other hand, brochure and flyer do not have enough space so the information is not as complete as marketing booklet. Therefore, marketing booklet is the best promotional tool rather than brochure and flyer.

The second advantage is Gunawangsa Manyar Hotel could reach the high class target. Brochure and flyer are usually spread to all kinds of people without spesicification of the target market. However, since brochure and flyer have limited information and bad quality paper, people mostly do not care about the brochure and flyer. Moreover, with the shape of a book the promotional tool looks more expensive, elegant, and qualified. This will help in reaching Gunawangsa Manyar Hotel's target market (companies and travel agencies) and raising the income of the hotel.

For the Business Communication Final Project, I decided to make a marketing booklet. The reason why I make this marketing booklet is because the information in it is very important to make people have a better understanding about Gunawangsa Manyar Hotel. The products that they sell can be recognized and trusted by potential customers. Therefore, it is very essential for Gunawangsa Hotel to have a marketing booklet. Compared to brochure and flyer, booklet has more complete information and more effective to solve Gunawangsa Hotel's problem.

First of all, the design of the marketing booklet is minimalist and contemporary. I made minimalist to keep it simple for the audience and also contemporary in order to make it more modern. I tried to adjust the branding with the booklet's color so I used red and white as the basic color because red is Gunawangsa Hotel's color and white looks more elegant. I used the same font and color to make it consistent in audience's eyes.

For the content of the marketing booklet, I chose four important components, such as Table of Contents, About Gunawangsa Manyar Hotel, Product description, and Contact Information. First, I decided to use those components because they are the main information needed by the potential customers in order to know more about Gunawangsa Manyar Hotel. People are usually looking for the information about what Gunawangsa Manyar Hotel, the types of rooms, facilities, and contact information. Therefore, those components are really important to be included in a marketing booklet.

In addition, the order of the components included in the marketing booklet also becomes one of the important points that will be my consideration in making this marketing booklet. I put "Table of Content" in the first order because it will help customers to find what they want to know or what pages they are looking for. This will be guidance for customers. Second is "Company Overview". In this part, I changed the term to "About Gunawangsa Hotel". The reason I put "About Gunawangsa Hotel" in the second order because this part will give an idea to customers about what business the company does. Therefore, the identity, benefits, and location of the hotel must be put in this part. I also put the first USP of Gunawangsa Hotel which is the price but only in statement form. Based on the interview result with six guests and the statement from sales people, one of the unique selling points of Gunawangsa Manyar Hotel is Cheap Price. 5 out of 6 guests of Gunawangsa Manyar Hotel said Gunawangsa Manyar Hotel is better in terms of price. Therefore, the cheap price become unique selling point of Gunawangsa Manyar Hotel. Also, if we compare to other three star hotels in Surabaya, Gunawangsa Manyar Hotel is cheaper. Third, I put "Product Description" on the third order because after knowing the identity of the company, customers will 
definitely want to know the detail of the product. As we know, product description's goal is to introduce the product of the hotel. Therefore, I put the four types of rooms of Gunawangsa Manyar Hotel with detail information and benefits of each room. By having detail information of the products, people will know more about Gunawangsa Hotel and can be convinced to stay in Gunawangsa Hotel. Next, I also put "Hotel's facilities" in product description part to let customers know what kind of facilities that Gunawangsa Hotel has. In this part, I put the second USP which is the restaurant and swimming pool as main facilities. I chose the restaurant and swimming pools as one of the USPs because 4 out of 6 of Gunawangsa Manyar Hotel's guest like to stay in Gunawangsa Manyar Hotel because the facilities are complete (The Restaurant and Swimming Pools). The restaurant provides various kinds of foods which are Western, Asian, and Indonesian food. The restaurant is also located on the $23^{\text {rd }}$ floor so it has a city view. In addition, Gunawangsa Manyar Hotel has two types of pools unlike the competitors. Therefore, complete facilities are also become the unique selling point of Gunawangsa Manyar Hotel.

Lastly, I put contact information on the last part of the booklet because it will help customers to reach the company. This part is one of the important things that should be listed in the last page. Therefore, it consists of address, website, telephone number, and social media account. With many contact options, it will give the customers the freedom to choose the suitable way to contact Gunawangsa Manyar Hotel.

\section{CONCLUSION}

For my Business Communication Final Project, I decided to make a marketing booklet for Gunawangsa Manyar Hotel, a three-star hotel in Surabaya. Before getting to the project, I had to do so many things since I did my project in another company. I had to find a new company, meet the representative, talk about the project, and negotiate whether they want to pay the cost of the project or not. After few weeks, I finally get the approval and they were willing to pay.

The idea of making this marketing booklet came up because there is a serious problem in Gunawangsa Manyar Hotel which can be solved using this marketing booklet. I found out that Gunawangsa Manyar Hotel did not have an effective promotional tool to introduce the hotel to the potential customers. They only have certain tools like brochure and flyer. In fact, these tools cannot emphasize the uniqueness of the hotel. In my opinion, it is important that Gunawangsa Manyar Hotel should promote the hotel with new promotional tool to reach potential customers. The new promotional tool that Gunawangsa Manyar Hotel need is a marketing booklet, which can help them to solve the problem. A marketing booklet will be very useful for the hotel because it could introduce directly and effectively to the companies and travel agencies.

There are four components in this marketing booklet. Those are table of contents, company overview, product description and contact information. Those components will help Gunawangsa Manyar Hotel in solving its problem because it can emphasize the uniqueness of the hotel. I used some concepts from online articles to arrange the content of this marketing booklet. Those concepts helped me a lot in writing the concept and contents of the booklet.

Finally, I hope that the marketing booklet can be used effectively by Gunawangsa Manyar Hotel. Gunawangsa Hotel can distribute this marketing booklet to companies which will reserve the room in a large number and also to travel agencies which can attract travelers.

\section{ACKNOWLEDGMENT}

First of all, I would like to thank God for helping me to complete this Business Communication Final Project (BCFP). I do not think that I could have finished this Business Communication Final Project smoothly without His help.

In addition, I would like to thank my advisor, Drs. Jusuf Ibrahim,MTESL, who always helps me and encourages me to complete my Business Communication Final Project. I am really grateful for his support and the knowledge he shares through this semester. Without his help, I do not think I could finish this Business Communication Final Project.

Moreover, I would like to thank Gunawangsa Manyar Hotel staff, Mr. Achmad Fathoni and Mr. Claudio Haren, who help and support me in completing my Business Communication Final Project too. Their contribution in the process to complete this project means much to me. 
Last, I would like to express my gratitude to my father, mother, and brother who always motivate me in completing this project. There is nothing that I can express my gratitude. Also, I would thank to my best friends, Windy Jiwono, William Zhang, Dea Minerva, Liza Tanri, Eliza Sucipto, Lisyeana, and Andreas Imanuel who always give their support, helps and cheer me up. Without the people I mentioned above, I would not have been able to finish my project and my BCFP report well.

\section{REFERENCES}

Davidson, K. How to Create a Marketing Booklet. Retrieved from <http://ehow.com/how_2172922_marketing-booklet.html>

Homor, T. (2012). Tips for Better Sales Booklets. Retrieved from $<$ https://www.business2community.com/marketing/tips-for-better-sales-booklets0274390> 